\title{
Efficacy of Capparis decidua in control of Lymnea acuminata and their cercaria larvae at Balsamand lake, J odhpur
}

\section{J yotsna Shekhawat ${ }^{1 *}$ and Naresh Vyas ${ }^{2}$}

${ }^{1}$ Department of Zoology \& Environmental Science, Lachoo Memorial College of Science \& Technology, Jodhpur (Rajasthan), INDIA

${ }^{2}$ Department of Zoology, Jai Narain Vyas University, Jodhpur (Rajasthan), INDIA

*Corresponding author. E-mail: jyotsnashekhawat@yahoo.com

Received:] uly 23, 2012; Revised received:M arch 8, 2013; Accepted:M arch 31, 2013

\begin{abstract}
The snail Lymnea acuminata is considered to be intermediate hosts because humans harbour the sexual stages of the parasites and the snails harbour the asexual stages. Herbs are believed to be safer than the synthetic drugs for the control of snails. Alcoholic extracts of Capparis decidua flowers have been evaluated for their lethal effect against L. acuminata and their cercarial larvae. $1 \%, 2 \%, 5 \%$ concentration of alcoholic flower extract of Capparis were not effective for cercaria after $9 \mathrm{hrs}$ of treatment. $100 \%$ mortality was not observed in echinostome

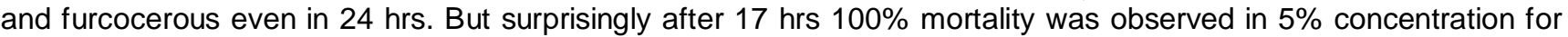
xiphdio.
\end{abstract}

Keywords: Capparis deciduas, Echinostome, Furcocerous, Lymnaea acuminate, Xiphidio

\section{INTRODUCTION}

The term freshwater bivalve is very inclusive and not very informative. There are representatives of at least 19 families that have at least one representative living in freshwater (Bogon et al., (2008). Positive associations have been suggested and sometimes shown between trematode prevalence in snails and the density of definitive hosts (Smith 2001), intermediate hosts (Hechinger et al., 2007), and the snail hosts themselves (Ewers, 1964). The snail Lymnaea acuminata Lamark (Lymnaeidae) is the vector of liver flukes, Fasciola gigantica Cobbold (Fascioliodae) and F. hepatica Linnaeus (Fascioliodae) which are responsible for endemic fascioliasis in cattle population. Molluscs feed on decaying organic matter as well as on planktons. Dead plant materials are also the major items in the diet of most species of terrestrial molluscs as well as freshwater mollusks (Dillon, 2000). Traditional medicines are important sources of potentially useful new compounds for the development of chemotherapeutic agents (Racio et al., 1989). The plant based natural constituents can be derived from any part of the plant like bark, leaves, flowers, roots, fruits, seeds, etc (Gordon and David, 2001) i.e. any part of the plant may contain active components. In addition, high cost and adverse side effects are commonly associated with popular synthetic antibiotic, the extracts from Capparis decidua, Acacia arabica, Dalbergia sissoo, Ricinus communis and Parthenium hysterophorus were evaluated for their repellent activity by Sharma (2003).

Snails have been studied for various parasitic infection of Balsamand Lake by Vyas and Shekhawat (2010). According to Farahnak et al. (2006) snail transmitted diseases are one of the major groups of helminth parasitic diseases which have been established by trematode parasites. The highest population of L. acuminata has been recorded in all seasons by Shekhawat and Vyas (2012). Therefore, the aim of the present study was to determine the efficacy of $C$. decidua for the control of $L$. acuminata and their cercaria larvae .

\section{METERIALS AND METHODS}

The snails were collected either handpicking or dragging a net through water and were transported to the laboratory. The snails were then transferred to glass water bowls and well aerated aquaria already provided a rich water plants like Hydrilla, Fimbria, Spirogyara,. The snail species were identified according to Tonapi (1980) and with the help of ZSI, Jodhpur. The L. acuminata was identified by its shell which is thin, oblong ovate, smooth, glossy externally and semi-translucent. The aperture is large and spirally twisted. Infected molluscan host usually showed "Gigentism" on examination and found that they were infected commonly with furcocerous, xiphidio, echinostome, monostome cercaria.

C. decidua is commonly known as kerda and kair is a small much branched tree or shrub of arid regions in Africa, Middle East and southern Asia, including the Thar Desert. The flowers are pink-red, single or in threes beside 
leaves and about $1 \mathrm{~cm}$ across. Flowers appear at the beginning of the dry season. Red conspicuous flowers appear in March to April and August-September and ripe by May and October. Selected plant flowers were collected directly from plants, dried and then finely powdered using a blender. The powder was subjected to alcoholic extraction following the method of Subramanian and Nagarjan (1969). Ten snails were placed in $100 \mathrm{ml}$ of individual concentration of each extract and mortality rate per hour was recorded after 6, 9, 11, 17, 24 and $48 \mathrm{hrs}$.

\section{RESULTS AND DISCUSSION}

The present study observed that alcoholic extracts of kair flower at 1\%,2\%, 5\% concentrations were not effective after $9 \mathrm{hrs}$ of treatment as all types cercariae survived. $100 \%$ mortality was observed for echinostome and furcocerous in $24 \mathrm{hrs}$. But surprisingly $100 \%$ mortality was observed in 5\% conc. for xiphdio after 17 hrs. The killing efficacy was low at lower concentration. However, Shekhawat et al. (2012 b) has reported that when M elania tuberculata was treated with Acacia arabica, . 100\% mortality was found immediately in 5\% concentration.Further, $1 \%, 5 \%, 10 \%$ concentrations of alcoholic extracts used for L. acuminata showed $100 \%$ mortality after $48 \mathrm{hr}, 24 \mathrm{hr}$, and $24 \mathrm{hr}$ respectively and $25 \%$ mortality was observed in $17 \mathrm{hrs}$ for $10 \%$ concentration of the extract.

The $5 \%$ concentration of flower extract of $C$. decidua was more effective for xiphidio because it gave $100 \%$ mortality but not for echinostome and furcocerous. Further, 5\% and 10\% concentration had more lethal effect than $1 \%$ concnetration. Thus, killing efficacy of the extracts declined at lower concentration. The efficacy of extracts of flower concentrations in present study was less in comparison to the study of Shekhawat et al., (2012 a) who reported $100 \%$ mortality for the same snails with the use of leaves of Azadirachata indica.

\section{REFERENCES}

Bogon, A.E. (2008) Global diversity of freshwater mussels in fresh water. Hydrobiologia, 595:139-147.
Dillon, R.T. (2000). The Ecology of Freshwater Molluscs. Cambridge University Press. 509pp.

Evers, W.H. (1964). The influence of the density of snails on the incidence of larval trematodes. Parasitol., 54: 579583.

Farahnak, A., Vafaie-Darian R., Mobedi I. (2006). A faunistic survey of cercariae from fresh water snails: Melanopsis spp. and their role in disease transmission. Iranian J. Publ. Health, 35(4):70-74.

Gordon, M.C. and David, J.N. (2001). Natural product drug discovery in the next millennium. Pharm. Biol., 39: 8-17.

Hechinger, R. F., Lafferty, K. D., Huspeni, T. C., Brooks, A. J. and Kuris, A.M. (2007). Can parasites be indicators of free-living diversity? Relationships between species richness and the abundance of larval trematodes and of local benthos and fishes. 0 ecologia, 151:82-92

Shekhawat, J. and Vyas, N. (2012). Population study of snails at Balsamand Lake. J ournal of Experimental Zoology, 15 (2):447-449.

Shekhawat, J., Vyas, N. and Gaur, D. (2012a). Effect of Azadirachata indica on controlling the Lymnea accuminata and their laeval trematodes at Balsamand Lake. J ournal of Applied Zoological Researches, 23(1): 59-63.

Shekhawat, J., Vyas, N. and Mirdha, S. (2012 b). Control of $M$ el ania tuber culata and their larval trematodes by Acacia arabica.National Conference Proceeding of P CFAZ], 9497

Racio, M.C., Rios J.C. and Villar, A. (1989). A review of some antimicrobial compounds isolated from medicinal plants. Phytotherapy Res., 3(4): 117-125.

Sharma, R. (2003). Medicinal plants of India - an encyclopedia, Daya Publishing house, New Delhi, pp. 4243.

Smith, N.F. (2001). Spatial heterogeneity in recruitment of larval trematodes to snail intermediate hosts. 0 ecologia, 127:115-122

Subramanian, S.S. and Nagarajan S. (1969). Flavonoids of the seeds of $\mathrm{C}$ rotlaria retusa and C. striata. Curr. Sci., 38:6568.

Tonapi, G. T. (1980). Freshwater animals of India, An ecological approach.Oxford and IBH Publishing Company, New Delhi.

Vyas, N. and Shekhawat,J. (2010). Studies on incidence of cercariae in fresh water mollusks in Balsamand Lake of Jodhpur. Hislopia J ournal, 3:173-175. 